Jurnal Indonesia Sosial Teknologi:p-ISSN: 2723 - 6609

e-ISSN : 2745-5254

Vol. 2, No.4 April 2021

\title{
PENGARUH ASSET GROWTH DAN OPERATING LEVERAGE TERHADAP STRUKTUR MODAL PADA PERUSAHAAN SEKTOR ANEKA INDUSTRI YANG TERDAFTAR DI BURSA EFEK INDONESIA PERIODE 2015-2019
}

\section{Jenal Alamsah}

Prodi Akuntansi STIE Dwimulya Serang

Email: Jeans_1468@yahoo.com

\section{Abstract}

The purpose of this study is to determine the effect of asset growth and operating leverage on capital structure, where the authors took 29 companies listed on the Indonesia Stock Exchange for the period 2012-2016. The method used is quantitative, where the method used to examine a specific population or sample, the instrument used is the financial statements of various industrial sector manufacturing companies from the sample of this study. The results of the study, partially for the asset growth variable, the $t_{\text {count }}$ was $4.097>t_{\text {table }} 1.976$ with a significance of $0.000<0.05$, thus asset growth had a significant effect on capital structure, while for thevariable, the Operating Leverage $t_{\text {cout }}$ was $0.991<t_{\text {table }} 1.976$, which This means that operating leverage does not have a significant effect on the capital structure. Meanwhile, for the simultaneous test results, obtained $f_{\text {coum }}$ of $36,879>f_{\text {table }} 3.06$ with a significance of $0.00<$ sig 0.05. Thus, the growth of assets and operating leverage together has a significant effect on the capital structure

Keyword: asset growth; operating leverage; capital structure

\begin{abstract}
Abstrak
Tujuan penelitian ini yaitu untuk mengetahui pengaruh pertumbuhan aset dan operating leverage terhadap struktur modal, dimana penulis mengambil sampel perusahaan yang terdaftar di Bursa Efek Indonesia periode 2012-2016 sebanyak 29 perusahaan. Metode yang digunakan adalah kuantitatif, dimana metode yang digunakan untuk meneliti pada populasi atau sampel tertentu, instrumen yang digunakan adalah laporan keuangan perusahaan manufaktur sektor aneka industri dari sampel penelitian ini. Hasil penelitian, secara parsial untuk variabel pertumbuhan aset diperoleh angka $t_{\text {hitung }}$ sebesar $4.097>t_{\text {tabel }} 1.976$ dengan signifikansi $0.000<0.05$ dengan demikian pertumbuhan aset berpengaruh signifikan terhadap struktur modal, sedangkan untuk variabel Operating Leverage didapatkan $\mathrm{t}_{\text {hitung }}$ sebesar $0.991<\mathrm{t}_{\text {abel }} 1.976$, yang berarti operating leverage berpengaruh tidak signifikan terhadap struktur modal. Sedangkan untuk hasil uji simultan, diperoleh $\mathrm{f}_{\text {hitumg }}$ sebesar $36.879>\mathrm{f}_{\text {tabel }} 3.06$ dengan signifikansi $0.00<\operatorname{sig} 0.05$. Dengan demikian pertumbuhan aset dan operatingleverage secara bersama-sama berpengaruh signifikan terhadap struktur modal.
\end{abstract}

Kata Kunci : pertumbuhan asset; operating leverage; struktur modal. 
Pengaruh Asset Growth dan Operating Leverage Terhadap Struktur Modal pada

Perusahaan Sektor Aneka Industri Yang Terdaftar di Bursa Efek Indonesia Periode

2015-2019

\section{Pendahuluan}

Struktur modal atau capital structure suatu perusahaan adalah sejumlah utang atau ekuitas yang dipergunakan oleh perusahaan dalam membiayai operasinya. Dengan demikian, perusahaan harus dapat memutusan apakah menggunakan utang atau ekuitas dalam membiayai operasinya dengan mempertimbangkan keseimbangan antara keduanya sehingga dapat menemukan struktur modal yang seimbang.

Struktur keuangan perusahaan menggambarkan bagaimana cara perusahaan mendanai aktivanya, baik dengan utang jangka pendek, utang jangka panjang ataupun modal pemegang saham. Selain digunakan dalam aktivitas, perusahaan juga membeli aset dimana semakin besar aset diharapkan semakin besar hasil operasi yang dihasilkan. Pertumbuhan aset didefinisikan sebagai perubahan tahunan dari total aktiva. Peningkatan aset yang diikuti peningkatan hasil operasi akan semakin menambah kepercayaan pihak luar terhadap perusahaan.

Pertumbuhan aset adalah perubahan total aset yang dimiliki oleh perusahaan. Perusahaan dengan tingkat pertumbuhan yang tinggi akan bergantung dari dana yang berasal dari luar perusahaan dikarenakan dana dari dalam perusahaan tidak mencukupi untuk mendukung tingkat pertumbuhan yang tinggi. (Brigham \& Houston, 2021). Dengan demikian perusahaan dengan tingkat pertumbuhan aset yang tinggi akan lebih banyak menggunakan hutang sebagai sumber modalnya daripada perusahaan dengan tingkat pertumbuhan yang rendah.

Struktur modal yang optimal adalah struktur modal perusahaan yang akan memaksimalkan harga sahamnya, (Brigham \& Houston, 2021). Kebijakan perusahaan dalam menentukan struktur modal melibatkan pertimbangan antara risiko dan tingkat pengembalian bila mengunakan lebih banyak hutang, sehingga dapat memperbesar expected rate of return. Oleh karena itu, semakin berkembang perusahaan, maka akan semakin besar kebutuhan biaya operasi perusahaan, salahsatunya adalah biaya tetap. Semakin besar beban tetap, maka semakin kecil keuntungan yang didapat. Rendahnya keuntungan yang didapat perusahaan dimungkinkan akan berakibat pada rendahnya nilai perusahaan (Fauzia \& Amanah, 2016).

Jika sebagian besar dari total biaya perusahaan adalah biaya tetap, maka Operating Leverage perusahaan tersebut tergolong tinggi, dengan demikian perusahaan yang memiliki Operating Leverage yang tinggi cenderung untuk mengurangi struktur modal guna memperkecil beban yang harus dikeluarkan (Abimanyu \& Wirasedana, 2015).

Sektor Aneka Industri merupakan sektor industri yang memiliki pangsa pasar yang luas seperti otomotif dan komponennya, kemudian tekstil, kabel dan elektronik, dengan demikian sektor ini merupakan perusahaan padat modal sehingga akan tergantung pada perubahan suku bunga maupun inflasi (Laili, 2018). Bila kedua hal teresebut meningkat, maka biaya akan meningkat sehingga penjualan dimungkinkan menurun. Karena sektor aneka industri merupakan industri padat modal, maka beban tetap pada industri ini cenderung tinggi sehingga akan memiliki pengaruh pada struktur 
modal. Penggunaan hutang sebagai pilihan dalam memenuhi kebutuhan biaya opearasi tentusaja pada akhirnya akan menimbulkan biaya tetap dalam hal ini berupa bunga atas hutang tersebut. Oleh karena hal tersebut penting untuk dipahami bagaimana perilaku Operating Leverage ini dapat berpengaruh terhadap struktur modal.

Penelitian tentang pengaruh Pertumbuhan Asset dan Operating Leverage yang dilakukan oleh (Tommy Mardiansyah, 2012) dengan hasil penelitian yang menunjukkan Operating Leverage berpengaruh negatif tidak signifikan terhadap struktur modal.

Sedangkan (Zuhro \& Suwitho, 2016), melakukan penelitian mengenai Debt to Equity Ratio dengan judul pengaruh ukuran perusahaan, pertumbuhan aset, dan profitabilitas terhadap struktur modal pada perusahaan Cosmetics and Household yang Terdaftar di Bursa Efek Indonesia, dengan hasil bahwa pertumbuhan aset berpengaruh tidak signifikan terhadap struktur modal. Tommy melakukan penelitian pada perusahaan makanan dan minuman sedangkan Zuhro pada perusahaan Cosmetics and Household, sedangkan penulis menggunakan perusahaan kelompok atau sektor aneka industry yang merupakan inndustri padat modal. Berdasarkan latar belakang tersebut, tujuan penelitian ini adalah untuk mengetahui pengaruh Asset Growth dan Operating Leverage terhadap Struktur Modal (Nasir et al., 2014).

Pecking order menggambarkan sebuah hirarki dalam pencarian dana perusahaan yang menunjukkan bahwa perusahaan lebih memilih menggunakan internal equity dalam membiayai investasi dan mengimplementasikannya sebagai peluang pertumbuhan.

Teori yang dikembangkan oleh Myers dan Majluf pada tahun 1984 ini menjelaskan urutan prioritas para manajer dalam menentukan sumber pendanaannya. Preferensi manajer dinyatakan dalam urutan sumber pendanaan yang dimulai dari pendanaan internal sebagai sumber utama. Pilihan prioritas berikutnya adalah hutang, dan yang terakhir berupa penerbitan saham.

Hal yang menarik dari pecking order theory ini tidak ada struktur modal yang optimal, namun memiliki susan hierarki pendanaan. Terdapat beberapa faktor yang mempengaruhi keputusan struktur modal perusahaan, seperti profitabilitas, pertumbuhan perusahaan, ukuran perusahaan, asset tangibility, likuiditas dan dividend payout (Bundala, 2012).

The Pecking Order theory menekankan permasalahan informasi asimetri. Perusahaan yang memiliki financial slack yang cukup tidak perlu menerbitkan risky debt atau saham untuk mendanai proyek - proyek barunya sehingga masalah informasi asimetri tidak akan muncul. Perusahaan akan dapat menerima seluruh proyek bagus tanpa harus merugikan pemegang saham lama. Teori ini merupakan penjelas perilaku perusahaan yang menahan sebagian laba dan membuat cadangan kas dalam jumlah yang cukup besar.

Leverage adalah penggunaan aset dan sumber dana (sources of funds) oleh perusahaan yang memiliki biaya tetap dengan maksud agar meningkatkan keuntungan potensial pemegang saham. Perusahaan menggunakan financial leverage dengan tujuan 
Pengaruh Asset Growth dan Operating Leverage Terhadap Struktur Modal pada Perusahaan Sektor Aneka Industri Yang Terdaftar di Bursa Efek Indonesia Periode

agar keuntungan yang diperoleh lebih besar daripada biaya aset dan sumber dananya, dengan demikian akan meningkatkan keuntungan pemegang saham.

Sebaliknya leverage juga meningkatkan variabilitaskeuntungan, karena jika perusahaan ternyata mendapatkan keuntungan yang lebih rendah dari biaya tetapnya maka penggunaan leverage akan menurunkan keuntungan pemegang saham.

Aset adalah semua kekayaan yang dimiliki perusahaan dan memberikan manfaat ekonomis di masa yang akan datang, oleh karena itu asset merupakan sumber daya yang digunakan dalam operasional perusahaan, semakin besar aset maka diharapkan semakin besar hasil operasional yang dihasilkan oleh perusahaan. Bagi perusahaan yang memiliki pertumbuhan yang tinggi, maka perusahaan membutuhkan dana dari luar perusahaan dikarenakan dana dari dalam perusahaan tidak mencukupi untuk mendukung tingkat pertumbuhan. Oleh karena itu perusahaan akan melakukan ekspansi dengan menggunakan dana eksternal berupa hutang.

Aset yang berubah-ubah setiap periodenya memberikan pendanganterhadap trend pertumbuhan aset yang akan memberikan efek pada keputusan manajemen dalam menentukan pengembangan perusahaan. Dalam penelitian ini untuk Asset Growth menggunakan rumus :

$$
\mathrm{ASG}=\frac{\text { TA_t }- \text { TA_t }-1}{\text { TA_t }-1}
$$

ASG: Asset Growth

TA_t: Total Asset Periode ini

TA_T-1: Total Asset Periode lalu

Operating Leverage adalah seberapa besar biaya tetap digunakan dalam operasi suatu perusahaan, hal ini menjelaskan bahwa leverage operasi merupakan penggunaan aktiva yang menimbulkan biaya tetap operasional.

Operating leverage yang tinggi akan berdampak pada Earning Before Interest and tax jika terjadi peningkatan pada penjualan, demikian juga bila terjadi penurunan pada penjualan sedangkan perusahaan memiliki tingkat operating leverage yang rendah, maka Earning Before Interest and taxakan mengalami penurunan. Degree Of Operating Leverage bagi sebuah perusahaan lebih merupakan fungsi dari proses produksi. Jika perusahaan menggunakan peralatan yang bersifat labor saving atau capital intensive dalam operasinya maka akan cenderung mempunyai biaya operasi tetap yang tinggi dan biaya operasi variabel yang relative rendah, maka akan menghasilkan degree of operating yang tinggi, sehingga perubahan penjualan akan mengakibatkan perubahan EBIT dalam persentase yang lebih besar.

Analisis leverage operasi dimaksudkan untuk mengetahui seberapa peka laba operasi terhadap perubahan hasil penjualan dan berapa penjualan minimal yang harus 
diperoleh agar perusahaan tidak menderita kerugian. Dengan demikian Operating Leverage dalam penelitian ini menggunakan:

$$
\mathrm{DOL}=\frac{\text { Perubahan EBIT }}{\text { Perubahan Penjualan }}
$$

Struktur modal adalah komposisi saham biasa, saham preferen, laba ditahan, dan utang jangka panjang yang dipertahankan oleh kesatuan usaha dalam mendanai aktiva. Dengan demikian struktur modal merupakan gambaran dari bentuk proporsi financial perusahaan yaitu antara modal yang dimiliki yang bersumber dari utang jangka panjang (long-term liabilities) dan modal sendiri (shareholders'equity) yang menjadi sumber pembiayaan suatu perusahaan.

Kebijakan hutang dapat diukur menggunakan Debt to Equity Ratio. Debt to equity ratio adalah perbandingan jumlah utang dengan modal sendiri yang mengukur persentase penggunaan dana yang berasal dari kreditur.

$$
\text { DER }=\frac{\text { Total Hutang }}{\text { Total Ekuitas }}
$$

\section{Metode Penelitian}

Jenis penelitian yang digunakan dalam penelitian ini adalah penelitian kausal yang bertujuan untuk menguji hipotesis tentang pengaruh satu (variabel independen) terhadap variabel lainnya (variabel dependen) (Sugiyono, 2014).

Variabel penelitian yang digunakan dalam penelitian ini adalah Asset Growth (X1), Operating Leverage (X2) dan Struktur Modal (Y) menggunakan data yang diperoleh dari laporan keuangan perusahaan sektor aneka industri yang terdaftar di bursa efek Indonesia periode 2015-2019.

Pengambilan sampel dalam penelitian ini menggunakan metode purposive sampling yaitu pemilihan sampel berdasarkan kriteria dengan tujuan untuk mendapatkan sampel yang representatif dan benar-benar dapat mewakili populasinya. Kriteria penentuan sampel adalah perusahaan sektor aneka industri yang konsisten mempublikasikan laporan keuangan selama periode penelitian. Dari hasil seleksi sample, diperoleh sebanyak 29 perusahaan.

Untuk melakukan pengujian, penulis menggunakan alat uji analisis statistic inferensial parametrik.Sebelum dilakukan uji regresi, terlebih dahulu dilakukan uji asumsi klasik karena menurut (Sunyoto, 2011) mengungkapkan bahwa model regresi linier berganda dapat disebut baik jika terbebas dari asumsi-asumsi klasik statistik, yaitu multikolinieritas, heteroskedastisitas, autokorelasi, dan normalitas data.

1. Uji Normalitas, bertujuan untuk menguji apakah dalam model variabel dependen dan variabel independen keduanya mempunyai distribusi normal atau tidak.Hal ini 
Pengaruh Asset Growth dan Operating Leverage Terhadap Struktur Modal pada Perusahaan Sektor Aneka Industri Yang Terdaftar di Bursa Efek Indonesia Periode

2015-2019

bertujuan untuk mengetahui jenis statistik yang cocok yang akan digunakan dalam menganalisis data. Model regresi yang baik adalah distribusi data normal atau mendekati normal. Uji ini dilakukan dengan cara melihat penyebaran data (titik) pada sumbu diagonal atau grafik. Apabila data menyebar disekitar garis diagonal dan mengikuti arah garis diagonal maka model regresi memenuhi asumsi normalitas.Apabila data menyebar jauh dari garis diagonal dan atau tidak mengikuti arah garis diagonal maka model regresi tidak memenuhi asumsi normalitas.Pengujian normalitas ini dapat dilakukan melalui analisis grafik dan analisis statistik.

Analisis Grafik, salah satu cara termudah untuk melihat normalitas residual adalah dengan melihat grafik histogram yang membandingkan antara data observasi dengan distribusi yang mendeteksi distribusi normal.Metode lain yang lebih handal adalah dengan melihat normal probability plot yang membandingkan distribusi kumulatif dari distribusi normal. Distribusi normal akan membentuk satu garis lurus diagonal dan ploting data residual akan dibandingkan dengan garis diagonal. Jika distribusi data residual normal, maka garis yang menggambarkan data sesungguhnya akan mengikuti garis diagonalnya.

Dasar pengambilan keputusan dengan analisis grafik adalah (Ghozali, 2016) :

a. Jika data menyebar disekitar garis diagonal dan mengikuti arah garis diagonal atau grafik histogramnya menunjukkan pola distribusi normal, maka model regresi memenuhi asumsi normalitas.

b. Jika data menyebar jauh dari diagonal dan/atau tidak mengikuti arah garis diagonal atau grafik histogramnya tidak menunjukkan pola distribusi normal, model regresi tidak memenuhi asumsi normalitas.

Selain grafik, Uji statistik normalitas dalam penelitian ini juga menggunakan uji Kolmogorov-Smirnov (Ghozali, 2016).

a. Apabila nilai Asymp. Sig. (1-tailed) kurang dari 0,05, maka Ho ditolak. Hal ini berarti data residual terdistribusi tidak normal.

b. Apabila nilai Asymp. Sig. (1-tailed) lebih besar dari 0,05, maka Ho diterima. Hal ini berarti data residual terdistribusi normal.

2. Uji Multikolinearitas, Uji ini digunakan untuk mengukur tingkat asosiasi (keeratan) hubungan atau pengaruh antar variabel bebas tersebut melalui besaran koefisien korelasi.Pemeriksaanmultikolinearitas dilakukan dengan menggunakan VIF (Variance Inflation Factor). Jika nilai VIF > 10 maka terdapat gejala multikolinearitas yang tinggi.

3. Uji Autokorelasi, Uji Autokorelasi adalah untuk melihat apakah terjadi korelasi antara variabel bebas terhadap variabel terikat, jadi tidak boleh ada gejala autokorelasi antara observasi dengan data observasi sebelumnya.Uji Durbin Watson atau DW test digunakan dalam pengujian autokorelasi. Dengan ketentuan: 
a. jika $0<\mathrm{d}<\mathrm{dl}$ maka tidak ada autokorelasi positif

b. jika dl $<\mathrm{d}<\mathrm{du}$ maka tidak ada autokorelasi positif

c. jika $4-\mathrm{dl}<\mathrm{d}<4$ maka tidak ada autokorelasi negatif

d. jika $4-\mathrm{du}<\mathrm{d}<4-\mathrm{dl}$ maka tidak ada autokorelasi negatif

e. jika du $<\mathrm{d}<4-$ du maka tidak ada autokorelasi positif atau negatif.

4. Uji Heteroskedastisitas, digunakan untuk mengetahui apakah ada perbedaan antara variance dari observasi yang satu dengan observasi yang lain. Jika residual mempunyai varians yang sama disebut homoskedastisitas dan jika varians tidak sama disebut heteroskedastisitas. Persamaan regresi yang baik jika tidak terjadi heteroskedastisitas. Salah satu cara untuk mendeteksi ada atau tidaknya heteroskedastisitas adalah dengan melihat grafik scatterplot antara nilai prediksi variabel dependen ZPRED dengan ini residualnya SRESID (Ghozali, 2016).

5. Analisis Regresi Linear Berganda, dilakukan untuk mengolah dan membahas data yang telah diperoleh dan untuk menguji hipotesis yang diajukan menggunakan persamaan:

$\mathrm{Y}=\alpha+\mathrm{b}_{1} \mathrm{X}_{1}+\mathrm{b}_{2} \mathrm{X}_{2}$

Dimana :

$\mathrm{Y}=$ Struktur Modal

$\mathrm{X}_{1}=$ Pertumbuhan Aset

$\mathrm{X}_{2}=$ Operating Leverage

$\alpha=$ Konstanta

$\mathrm{b}_{1, \mathrm{~b}_{2}}=$ Koefisien regresi parsial

6. Uji Hipotesis, adalah metode pengambilan keputusan berdasarkan data hasil proses analisis. Dalam statistik, sebuah hasil bisa dikatakan signifikan secara statistik jika kejadian tersebut hampir tidak mungkin disebabkan oleh faktor yang kebetulan sesuai dengan batas probabilitas yang sudah ditentukan sebelumya.

a. Uji t (Parsial), Uji Parsial adalah uji untuk melihat bagaimana pengaruh masingmasing variabel bebas secara sendiri-sendiri terhadap variabel terikat, uji ini dilakukan dengan membandingkan t-hitung dengan t-tabel atau dengan melihat signifikansi pada masing-masing t hitung. Untuk melakukan uji parsial (uji t), terlebih dahulu menentukan $\mathrm{t}$ tabel yang diperoleh berdasarkan $\mathrm{df}=\mathrm{n}-\mathrm{k}-1$ dengan probabilitas $5 \%$.

Sedangkan pengambilan keputusan adalah Jika $t$ hitung $<\mathrm{t}$ tabel maka Ho diterima dan Ha ditolak atau pertumbuhan aset berpengaruh tidak terhadap struktur modal dan Jika t hitung > t tabel maka Ho ditolak dan Ha diterima atau pertumbuhan aset berpengaruh signifikan terhadap struktur modal.

b. Uji F (Simultan), adalah uji untuk melihat pengaruh semua variabel independen secara bersama-sama terhadap variabel dependen atau untuk menguji kelayakan sebuah model penelitian. Untuk melakukan uji $F$, terlebih dahulu ditentukan $f$ tabel dengan menggunakan df1 = variabel-1dan df2 = n-k-1, Sedangkan 
Pengaruh Asset Growth dan Operating Leverage Terhadap Struktur Modal pada Perusahaan Sektor Aneka Industri Yang Terdaftar di Bursa Efek Indonesia Periode

pengambilan keputusan adalah Jika $\mathrm{f}$ hitung $<\mathrm{f}$ tabel maka Ho diterima dan $\mathrm{Ha}$ ditolak atau Pertumbuhan aset dan Operating Leverage secara bersama-sama berpengaruh tidak signifikan terhadap struktur modal, dan Jika f hitung > f tabel maka Ho ditolak dan Ha diterima atau Pertumbuhan Aset dan Operating Leverage secara bersama-sama berpengaruh signifikan terhadap struktur modal.

7. Uji Koefisien Determinasi, untuk mengetahui seberapa besar pengaruh seluruh variabel independen secara bersama-sama terhadap variabel dependen menggunakan angka R Square (angka korelasi yang dikuadratkan). Angka R Square disebut juga sebagai Koefisien Determinasi (Ghozali, 2016). Besarnya pengaruh dapat dihitung dengan rumus $\mathrm{KD}=\mathrm{R}$ Square $\mathrm{x} 100 \%$. Sedangkan sisanya adalah pengaruh variabel lain diluar variabel penelitian sebesar $100 \%$ - KD.

\section{Hasil dan Pembahasan}

Tabel 1.1

Hasil Uji Kolmogorov Smirnov

\begin{tabular}{llr}
\hline & & $\begin{array}{r}\text { Unstandardized } \\
\text { Residual }\end{array}$ \\
\hline $\mathrm{N}$ & & 145 \\
\hline Normal Parameters $^{\mathrm{a}}$ & Mean & .0000000 \\
\cline { 2 - 3 } & Std. Deviation & 1.23259510 \\
\hline Most Extreme & Absolute & .103 \\
\cline { 2 - 3 } Differences & Positive & .103 \\
\cline { 2 - 3 } & Negative & -.102 \\
\hline Kolmogorov-Smirnov Z & & 1.246 \\
\hline Asymp. Sig. (2-tailed) & & .090 \\
\hline
\end{tabular}

Uji normalitas dengan menggunakan One-Sample Kolmogorov-Smirnov, sehingga dapat dipastikan bahwa data data berdistribusi normal, dimana berdasarkan Tabel 1.1 nilai signifikan sebesar 0,09 hal ini berarti nilai sig $>0,05$ dengan demikian dapat disimpulkan bahwa data berdistribusi normal.

Tabel 1.2

Hasil Uji Multikolonieritas

\begin{tabular}{|c|c|c|c|}
\hline & \multirow[t]{2}{*}{ Model } & \multicolumn{2}{|c|}{ Collinearity Statistics } \\
\hline & & Tolerance & VIF \\
\hline \multirow[t]{3}{*}{1} & (Constant) & & \\
\hline & PAS & 0.978 & 1.023 \\
\hline & DOL & 0.992 & 1.008 \\
\hline
\end{tabular}

Uji Multikolonieritas diperoleh nilai $\mathrm{VIF}<10$ dengan demikian disimpulkan tidak terjadi multikolinier, karena nilai $\mathrm{VIF}<10$. 
Tabel 1.3

Hasil Uji Autokorelasi

\begin{tabular}{lrrr}
\hline $\mathrm{R}$ & R Square & \multicolumn{1}{c}{$\begin{array}{c}\text { Adjusted R } \\
\text { Square }\end{array}$} & $\begin{array}{l}\text { Durbin- } \\
\text { Watson }\end{array}$ \\
\hline $.664^{\mathrm{a}}$ & .441 & .429 & 2.005 \\
\hline
\end{tabular}

Uji Autokorelasi diperoleh nilai DW 2.005 sedangkan dari table Durbin Watson dengan signifikansi $5 \%, \mathrm{n}=145$ serta $\mathrm{k}=2$ diperoleh nilai du sebesar 1.7566.dengan demikian $\mathrm{du}<\mathrm{DW}<4$-du atau $1.7566<2.005<2,243$. Dapat disimpulkan bahwa tidak terjadi autokorelasi atau negatif. Sedangkan hasil uji statistik terhadap data penelitian penulis sajikan berikut ini:

Tabel 1.4

Hasil uji Regresi

\begin{tabular}{llrr}
\hline & \multirow{2}{*}{ Model } & \multicolumn{2}{c}{ Unstandardized Coefficients } \\
\cline { 3 - 4 } & & $\mathrm{B}$ & Std. Error \\
\hline \multirow{2}{*}{1} & (Constant) & .852 & .113 \\
\cline { 2 - 4 } & ASG & 2.402 & .586 \\
\cline { 2 - 4 } & DOL & -.041 & .042 \\
\hline
\end{tabular}

Berdasarkan Tabel 1.4 dibentuk persamaan regresi berganda sebagai berikut :

$\mathrm{Y}=0,852+2,402$ ASG $-0,041$ DOL

Persamaan regresi tersebut diinterpretasikan bahwa struktur modal bernilai 0,852 jika pertumbuhan aset dan operating leverage bernilai konstan. Jika pertumbuhan aset naik satu satuan dan operating leverage bernilai konstan maka struktur modal akan bertambah sebesar 2,402 sedangkan jika operating leverage naik satu satuan dan pertumbuhan aset bernilai konstan maka struktur modal akan turun sebesar 0,041.

Untuk pengambilan keputusan penerimaan atau penolakan hipotesis dalam uji parsial (Uji t), terlebih dahulu ditentukan $t_{\text {table }}$ dengan taraf signifikansi $5 \% \mathrm{df}=\mathrm{n}-\mathrm{k}$ dimana $\mathrm{df}=145-2=143$ dengan uji dua sisi diperoleh $\mathrm{t}_{\text {tabel }}$ sebesar 1,97669

Tabel 1.5

Hasil uji t (Parsial)

\begin{tabular}{|c|c|c|c|}
\hline Model & $\begin{array}{l}\text { Standardized } \\
\text { Coefficients }\end{array}$ & $\mathrm{t}$ & Sig. \\
\hline 1 (Constant) & & 7.511 & .000 \\
\hline ASG & .325 & 4.097 & .000 \\
\hline DOL & -.079 & -.991 & .323 \\
\hline
\end{tabular}


Pengaruh Asset Growth dan Operating Leverage Terhadap Struktur Modal pada Perusahaan Sektor Aneka Industri Yang Terdaftar di Bursa Efek Indonesia Periode

2015-2019

Berdasarkan table 1.5 Nilai thitung untuk variabel pertumbuhan aset sebesar 4,097 dengan demikian 4,097 > 1,97669 yang berarti $t_{\text {hitung }}>t_{\text {tabel. }}$. Dengan demikian Ho ditolak dan Ha diterima atau pertumbuhan aset berpengaruh signifikan terhadap struktur modal. Sedangkan nilai $t_{\text {hitung }}$ untuk variabel operating leverage sebesar -0,991 dengan demikian -0,991 < 1,97669 yang berarti $t_{\text {hitung }}<t_{\text {table. }}$. Dengan demikian Ho diterima dan Ha ditolak atau operating leverage berpengaruh tidak signifikan terhadap struktur modal.

Tabel 1.6

Hasil uji f (simultan)

\begin{tabular}{llrrrrr}
\hline Model & $\begin{array}{c}\text { Sum of } \\
\text { Squares }\end{array}$ & df & $\begin{array}{c}\text { Mean } \\
\text { Square }\end{array}$ & F & Sig. \\
\hline \multirow{2}{*}{1} & Regression & 108.327 & 3 & 36.109 & 36.879 & $.000^{\mathrm{a}}$ \\
\cline { 2 - 7 } & Residual & 137.076 & 140 & .979 & & \\
\cline { 2 - 6 } & Total & 245.403 & 143 & & & \\
\hline
\end{tabular}

Untuk pengambilan keputusan penerimaan atau penolakan hipotesis dalam uji simultan (Uji f), terlebih dahulu ditentukan $\mathrm{f}_{\text {table }}$ dengan taraf signifikan $5 \%$ df $1=$ Variabel- 1 dimana $\mathrm{df} 1=3-1=2$ dan $\mathrm{df} 2=\mathrm{n}-\mathrm{k}$ dimana $\mathrm{df} 2=145-2=143$ sehingga

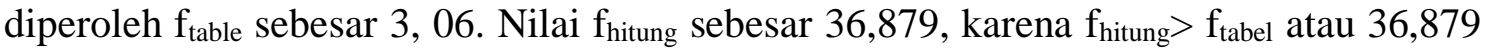
$>$ 3,06 maka Ho ditolak dan Ha diterima atau pertumbuhan aset dan operating leverage secara bersama-sama berpengaruh signifikan terhadap struktur modal.

Untuk menghitung besarnya pengaruh pertumbuhan aset dan operating leverage terhadap struktur modal menggunakan rumus $\mathrm{KD}=\mathrm{R}$ square $\mathrm{x} 100 \%$. Dengan demikian berdasarkan table 1.3 diperoleh nilai $\mathrm{R}$ square sebesar 0.441 , mka $\mathrm{KD}=0,441 \times 100=$ $44,1 \%$ yang berarti besarnya pengaruh pertumbuhan aset dan operating leverage terhadap struktur modal sebesar $44,1 \%$ sedangkan sisanya $100 \%-44,1 \%=55,9 \%$ dipengaruhi variabel diluar model penelitian.

Berdasarkan hasil output uji hipotesis secara parsial (Uji t) untuk Asset Growth menunjukkan bahwa $t_{\text {hitung }}>t_{\text {tabel }}(4,097>1,97669)$ maka artinya bahwa Asset Growth berpengaruh signifikan terhadap struktur modal. Dengan adanya peningkatan aset yang diikuti peningkatan hasil operasional akan menambah kepercayaan investor untuk menanamkan modal terhadap perusahaan. Hal ini didasarkan pada keyakinan investor atas dana yang ditanamkan ke dalam perusahaan dijamin oleh besarnya aset yang dimiliki perusahaan. Disisi lain peningkatan proporsi utang yang lebih besar dari pada modal sendiri menunjukkan proporsi total aset semakin besar.Semakin tinggi tingkat pertumbuhan perusahaan maka semakin besar pula aset yang yang bisa digunakan sebagai jaminan perusahaan untuk berhutang sehingga dapat meningkatkan struktur modal perusahaan tersebut. Atau jika aset yang dimiliki perusahaan banyak, maka perusahaan akan lebih suka menggunakan hutang jangka panjang. Sebaliknya pada perusahaan dengan tingkat pertumbuhan yang lambat lebih sedikit menggunakan hutang sehingga memperkecil struktur modal.

Untuk Operating Leverage, menunjukkan bahwa $t_{\text {hitung }}<t_{\text {tabel }}(0,991<1,97669)$ sehingga Operating Leverage berpengaruh tidak signifikan terhadap struktur modal, hipotesis ini di dukung oleh penelitian yang dilakukan (Tommy Mardiansyah, 2012) operating leverage merupakan biaya tetap yang dilakukan dalam operasional perusahaan sehingga konsisten yang menyatakan operating leverage berpengaruh tidak 
signifikan terhadap struktur modal.Operating Leverage mempunyai hubungan negatif terhadap struktur modal yang artinya semakin tinggi Operating Leverage maka akan semakin rendah pula tingkat utang perusahaan. tetapi perubahannya tidak signifikan terhadap struktur modal. Dalam menambah hutang perusahaan manufaktur sektor aneka industri tidak terlalu memperhatikan tingkat operating leverage yang mencerminkan risiko bisnisnya. Hal ini disebabkan karena risiko bisnis perusahaan manufaktur sektor aneka industri tergolong rendah, sehingga dalam penentuan penggunaan hutang kurang diperhatikan risiko bisnisnya karena perusahaan manufaktur sektor aneka industri merupakan salah satu industri perekonomian di Indonesia.

Berdasarkan uji f (simultan) pengaruh Asset Growth dan operating leverage terhadap struktur modal, diperoleh $\mathrm{f}_{\text {tabel }}$ sebesar 3,06 dan nilai $\mathrm{f}_{\text {hitung }}$ sebesar 36,879 karena $f_{\text {hitung }}>f_{\text {tabel }}$ atau 36,879 > 3,06 maka Pertumbuhan aset dan operating leverage bersama-sama berpengaruh signifikan terhadap Struktur modal. Sedangkan besarnya pengaruh Asset Growth dan operating leverage terhadap struktur modal (Y) adalah sebesar 44,1\% sedangkan sisanya $100 \%-44,1 \%=55,9 \%$ dipengaruhi variabel lain diluar model penelitian, seperti Profitabilitas, Ukuran Perusahaan, Struktur Aktiva, Likuiditas dll.

\section{Kesimpulan}

Jika pertumbuhan aset meningkat akan berpengaruh terhadap struktur modal karena dengan meningkatnya jumlah aset akan mendapatkan kepercayaan dari pihak luar (kreditur) terhadap perusahaan sehingga dibutuhkan perusahaan mendapatkan dana dari luar dalam bentuk hutang. Operating Leverage merupakan ukuran yang memperlihatkan sejauh manaperusahaan dalam membiayai aktivanya menggunakan pembiayaan utang (total utang) dalam struktur modal perusahaan untuk membiayai kegiataanperusahaan.

Sedangkan Asset Growth dan operating leverage secara bersama-sama berpengaruh signifikan terhadap struktur modal pada perusahaan manufaktur sektor aneka industri yang terdaftar di Bursa Efek Indonsia tahun 2015-2019.Besarnya pengaruh Asset Growth dan operating leverage terhadap struktur modal sebesar $44,1 \%$ sedangkan sisanya $100 \%-44,1 \%=55,9 \%$ dipengaruhi variabel lain diluar model penelitian seperti Profitabilitas, Ukuran Perusahaan, Struktur Aktiva, Likuiditas dll.

Berdasarkan hasil penelitian, saran untuk penelitian selanjutnya diharapkan dapat menggunakan sampel yang lebih besar seperti menggunakan sampel aneka industry atau industry yang homogeny sehingga mendapatkan gambaran lebih luas tentang pengaruh Asset Growth dan Operating Leverage terhadap Struktur Modal. Selain menggunakan sample lebih besar, karena pengaruh secara bersama-sama hanya sebesar 44,1\% maka peneliti selanjutnya agar menambahkan variabel lainnya sebagai upaya untuk mengetahui pengaruh variable lain terhadap Struktur Modal. 
Pengaruh Asset Growth dan Operating Leverage Terhadap Struktur Modal pada Perusahaan Sektor Aneka Industri Yang Terdaftar di Bursa Efek Indonesia Periode

2015-2019

\section{Bibliography}

Abimanyu, M. K. A., \& Wirasedana, W. P. (2015). Pengaruh Ukuran Perusahaan, Variabilitas Pendapatan Dan Operating Leverage Pada Struktur Modal Industri Perbankan. E-Jurnal Akuntansi, 11(3), 848-862.

Brigham, E. F., \& Houston, J. F. (2021). Fundamentals of financial management. Cengage Learning.

Bundala, N. N. (2012). Do Tanzanian companies practice pecking order theory, agency cost theory or trade-off theory? An empirical study in Tanzanian listed companies. International Journal of Economics and Financial Issues, 2(4), 401-422.

Fauzia, N., \& Amanah, L. (2016). Pengaruh intellectual capital, karakteristik perusahaan, dan corporate social responsibility terhadap nilai perusahaan. Jurnal Ilmu Dan Riset Akuntansi (JIRA), 5(4).

Ghozali. (2016). Aplikasi Analisis Multivariete Dengan Program IBM SPSS 23. Universitas Diponegoro.

Ghozali, I. (2011). Aplikasi analisis multivariate dengan program IBM. Spss.

Laili, C. N. (2018). Pengaruh Corporate Governance, Corporate Social Responsibility, Ukuran Perusahaan Terhadap Nilai Perusahaan: Kinerja Keuangan Sebagai Varibel Mediasi (Studi Pada Perusahaan Manufaktur Yang Terdaftar Di Bei). Universitas Brawijaya.

Mardiansyah, T. (2012). Pengaruh Profitabilitas dan Operating Leverage terhadap Struktur Modal Perusahaaan Makanan dan Minuman yang terdaftar di Bursa Efek Indonesia. Jurnal Ekonomi. Universitas Negeri Padang.

Nasir, A., Junita, M., \& Ilham, E. (2014). Pengaruh profitabilitas, pertumbuhan aset, operating leverage, dan ukuran perusahaan terhadap struktur modal studi empiris pada perusahaan food and beverages yang terdaftar di bursa efek indonesia periode 2010-2012. Riau University.

Sugiyono, M. (2014). Penelitian Pendidikan Pendekatan Kuantitatif Kualitatif R\&D cet. Ke-19, Bandung: Alfabeta.

Sunyoto, D. (2011). Analisis regresi dan uji hipotesis. Yogyakarta: Caps.

Zuhro, F., \& Suwitho, S. (2016). Pengaruh ukuran perusahaan, pertumbuhan aset, dan profitabilitas terhadap struktur modal. Jurnal Ilmu Dan Riset Manajemen (JIRM), $5(5)$. 